\title{
Mineralization of antibiotic sulfamethoxazole by photoelectro-Fenton treatment using activated carbon fiber cathode and under UVA irradiation
}

\author{
Aimin Wang ${ }^{\mathrm{a}, \mathrm{b}, *}$, Yu-You Li ${ }^{\mathrm{a}, \mathrm{c}}$, Adriana Ledezma Estrada ${ }^{\mathrm{a}}$ \\ a Graduate School of Environmental Studies, Tohoku University, 6-6-06 Aza-Aoba, Aramaki, Aoba-ku, Sendai, Miyagi 980-8579, Japan \\ b State Key Laboratory of Environmental Aquatic Chemistry, Research Center for Eco-Environmental Sciences, Chinese Academy of Sciences, Beijing 100085, China \\ ${ }^{c}$ Department of Environmental and Municipal Engineering, Tianjin Institute of Urban Construction, Jinjinggonglu 26, Tianjin 300384, China
}

\section{A R T I C L E I N F O}

\section{Article history:}

Received 7 September 2010

Received in revised form 3 December 2010

Accepted 4 December 2010

Available online 13 December 2010

\section{Keywords:}

Sulfamethoxazole

Photoelectro-Fenton

Activated carbon fiber cathode

Mineralization

\begin{abstract}
A B S T R A C T
The mineralization of antibiotic sulfamethoxazole (SMX) of concentrations up to $300 \mathrm{mg} \mathrm{L}^{-1}$ was examined by photoelectro-Fenton (PEF) using an activated carbon fiber (ACF) cathode with UVA ( $365 \mathrm{~nm}$ ) irradiation. Comparative mineralization has been studied by different methods: $\mathrm{RuO}_{2} / \mathrm{Ti}$ anodic oxidation (AO), $\mathrm{AO}$ in the presence of electrogenerated $\mathrm{H}_{2} \mathrm{O}_{2}\left(\mathrm{AO}-\mathrm{H}_{2} \mathrm{O}_{2}\right), A O-\mathrm{H}_{2} \mathrm{O}_{2}$ in the presence of UVA $\left(\mathrm{AO}-\mathrm{H}_{2} \mathrm{O}_{2}\right.$-UVA), and both the electro-Fenton (EF) and PEF processes. PEF treatment at a low applied current of $0.36 \mathrm{~A}$ yields a faster and more complete depollution with $80 \%$ of the TOC removed after $6 \mathrm{~h}$ of electrolysis. The higher oxidative ability of the PEF process can be attributed to the additional hydroxyl radicals $(\bullet \mathrm{OH})$ produced by the photo-Fenton reaction. The $63 \%$ mineralization in the case of EF treatment was due to the formation of short intermediates, such as carboxylic acids, which were difficult to oxidise with $\bullet \mathrm{OH}$. In the $\mathrm{AO}-\mathrm{H}_{2} \mathrm{O}_{2}$-UVA process, about $36 \%$ of the TOC was removed after $6 \mathrm{~h}$ electrolysis, while $28 \%$ of the TOC was removed in the $\mathrm{AO}-\mathrm{H}_{2} \mathrm{O}_{2}$ process. SMX is only slightly mineralized by the AO process, with only $25 \%$ of the TOC removed. HPLC-MS analysis allowed for up to six aromatic reaction products to be identified during the SMX degradation in the PEF process, mainly formed from the hydroxylation of the aromatic ring or/and isoxazole ring, accompanied by the substitution of the amine group (on aromatic cycle) or methyl group (on isoxazole ring) by $\bullet \mathrm{OH}$. The carboxylic acids generated, including oxalic, maleic, oxamic, formic and acetic acids, were detected by ion-exclusion chromatography. The initial organic nitrogen was mainly converted into $\mathrm{NH}_{4}{ }^{+}$along with a very small proportion of $\mathrm{NO}_{3}{ }^{-}$ion. Considering all the oxidation intermediates and end products for SMX degradation in the PEF process, a general mineralization mechanism by $\bullet \mathrm{OH}$ and UVA was proposed.
\end{abstract}

(C) 2010 Elsevier B.V. All rights reserved.

\section{Introduction}

Sulfamethoxazole (SMX, Table 1), one of the most prescribed pharmaceuticals, is a synthetic antimicrobial frequently used in human medicine to treat bronchitis and urinary tract infections and also in veterinary medicine, not only to prevent and treat infections, but also to promote growth in food-producing animals [1]. After use, the substance is metabolized in the liver and its unmetabolized form (about 15\% of the administrated dose [2,3]) is excreted with urine or feces, then enters wastewater and is ultimately discharged into conventional wastewater treatment plants (WWTPs). Increasing concern regarding antibacterials in the past few years stems from the fact that these substances continually being intro-

\footnotetext{
* Corresponding author at: Graduate School of Environmental Studies, Tohoku University, 6-6-06 Aza-Aoba, Aramaki, Aoba-ku, Sendai, Miyagi 980-8579, Japan. Tel.: +8122795 7464; fax: +81227957465.

E-mail address: wangaimin76@hotmail.com (A. Wang).
}

duced into the environment may stimulate the dissemination of antibacterial resistance among native bacterial populations, which would make it more difficult to treat infections, and have implications in terms of morbidity, mortality, and economic cost $[1,4,5]$. As such, it is important to remove antibacterial agents completely and as quickly as possible at their source (e.g. manure), before resistance to the agents can be developed in microorganisms and then spread into the environment [4]. Although past studies have demonstrated that sulfonamides are biodegraded in sewage, the extent of the biodegradation is quite limited and the processes are typically too slow to ensure their complete elimination from treated wastewater effluent. As a result, SMX has been frequently detected in municipal wastewater and surface water bodies in recent years [6]. Research efforts are underway to develop powerful oxidation techniques which will allow for their overall destruction from wastewater, and thus avoid the dangerous accumulation of SMX in the aquatic environment. Several authors have described methods for a quick removal of SMX from waters by advanced oxidation processes (AOPs) which produce hydroxyl radicals $(\bullet \mathrm{OH})$ 
Table 1

Sulfamethoxazole (SMX).

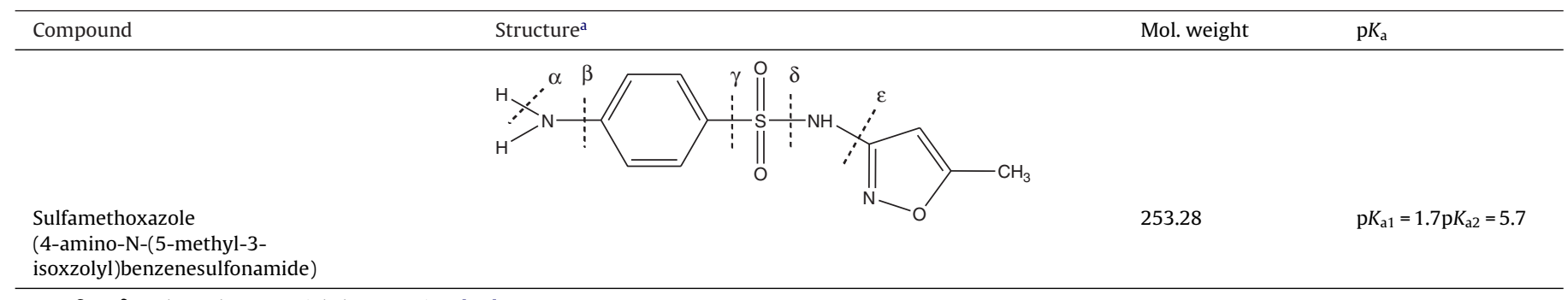

a $\alpha, \beta, \gamma, \delta, \varepsilon$ show the potential cleavage sites [46].

and effectively either eliminate SMX or transform it into lesstoxic more biodegradable intermediates, such as ferrate $[7,8], \mathrm{O}_{3}$ [9-14], $\mathrm{O}_{3} / \mathrm{H}_{2} \mathrm{O}_{2}$ [11], $\mathrm{TiO}_{2}$ photocatalysis [14-17], UV photolysis [18-20], $\mathrm{UV} / \mathrm{H}_{2} \mathrm{O}_{2}$ [2,21], photo-Fenton [22,23], as well as solar photo-Fenton [24-27]. The metabolites formed during SMX oxidation, however, may also be harmful compounds and need to be removed from water. Therefore, the complete mineralization is a better approach to dealing with SMX in the wastewater.

Electrochemical advanced oxidation processes (EAOPs) like anodic oxidation and indirect oxidation based on $\mathrm{H}_{2} \mathrm{O}_{2}$ electrogeneration have attracted a lot of attention for use in wastewater decontamination not only due to their low cost and high effectiveness but also because they do not produce dangerous waste. Anodic oxidation needs an active anode, such as a boron-doped diamond (BDD) anode. The anodic oxidation of SMX at the BDD anode has been investigated by several authors [28,29]. The most common of the indirect electrooxidation methods is electro-Fenton (EF), which is based on the continuous supply of $\mathrm{H}_{2} \mathrm{O}_{2}$ generated from two electron reduction of oxygen on the catalytic cathode, such as carbon felt [30,31], $\mathrm{O}_{2}$-PTFE cathode [32-37] and activated carbon fiber (ACF) $[38,39]$ to a contaminated acid solution containing $\mathrm{Fe}^{2+}$ or $\mathrm{Fe}^{3+}$ as catalyst. A recent study has shown that the EF process can degrade antibiotic SMX efficiently [40].

$\mathrm{O}_{2}+2 \mathrm{H}^{+}+2 \mathrm{e}^{-} \rightarrow \mathrm{H}_{2} \mathrm{O}_{2} \quad E^{\circ}=0.695 \mathrm{~V} / \mathrm{NHE}$

$\mathrm{Fe}^{2+}+\mathrm{H}_{2} \mathrm{O}_{2}+\mathrm{H}^{+} \rightarrow \mathrm{Fe}^{3+}+\mathrm{H}_{2} \mathrm{O}+\cdot \cdot \mathrm{OH}$

$\mathrm{Fe}^{3+}+\mathrm{e}^{-} \rightarrow \mathrm{Fe}^{2+} \quad E^{\circ}=0.77 \mathrm{~V} / \mathrm{NHE}$

$\mathrm{H}_{2} \mathrm{O} \rightarrow 1 / 2 \mathrm{O}_{2}+2 \mathrm{H}^{+}+2 \mathrm{e}^{-} \quad E^{\circ}=1.23 \mathrm{~V} / \mathrm{NHE}$

The photoelectro-Fenton (PEF) process is a modification of the EF process in which the solution treated under EF conditions is simultaneously irradiated with UVA $\left(\lambda_{\max }=360 \mathrm{~nm}\right)[32,37]$ or UVC $\left(\lambda_{\max }=254 \mathrm{~nm}\right)$ light [39]. The complex mechanism of UV irradiation can be attributed to the following [41]: (i) the production of greater amounts of $\bullet \mathrm{OH}$ from the photoreduction of $\mathrm{Fe}(\mathrm{OH})^{2+}$, which is the predominant $\mathrm{Fe}^{3+}$ species at $\mathrm{pH} 3.0$, via photo-Fenton by reaction (5), and (ii) the photolysis of complexes of $\mathrm{Fe}(\mathrm{III})$ with generated carboxylic acids, such as oxalic acid, which is produced during the oxidation of most organics, and the fast photolysis of $\mathrm{Fe}(\mathrm{III})$-oxalate complexes $\left(\mathrm{Fe}\left(\mathrm{C}_{2} \mathrm{O}_{4}\right)^{+}, \mathrm{Fe}\left(\mathrm{C}_{2} \mathrm{O}_{4}\right)_{2}{ }^{-}, \mathrm{Fe}\left(\mathrm{C}_{2} \mathrm{O}_{4}\right)_{3}{ }^{3-}\right.$ shown as reaction (6). When UVC was used as the light source, $\mathrm{H}_{2} \mathrm{O}_{2}$ absorbed radiation with a molar absorption coefficient of 18.6 $\mathrm{LM}^{-1} \mathrm{~s}^{-1}$, and it decomposed with a quantum yield of 0.98 generating $\bullet \mathrm{OH}$ radicals (Eq. (7)) [39]. The PEF process has been well proven to be a very efficient method for complete mineralization of a lot of refractory organic pollutants in the wastewaters [42-45].

$$
\begin{aligned}
& \mathrm{Fe}(\mathrm{OH})^{2+}+h v \rightarrow \mathrm{Fe}^{2+}+\cdot \mathrm{OH} \\
& 2 \mathrm{Fe}\left(\mathrm{C}_{2} \mathrm{O}_{4}\right)_{n}{ }^{(3-2 n)}+h v \rightarrow 2 \mathrm{Fe}^{2+}+(2 n-1) \mathrm{C}_{2} \mathrm{O}_{4}{ }^{2-}+2 \mathrm{CO}_{2} \\
& \mathrm{H}_{2} \mathrm{O}_{2}+h v \rightarrow 2 \cdot \mathrm{OH}
\end{aligned}
$$

The aim of this study was to determine the potential of PEF for the complete mineralization of $200 \mathrm{mg} \mathrm{L}^{-1} \mathrm{SMX}$ aqueous solutions. PEF was compared to anodic oxidation (AO), AO in presence of electrogenerated $\mathrm{H}_{2} \mathrm{O}_{2}\left(\mathrm{AO}-\mathrm{H}_{2} \mathrm{O}_{2}\right), \mathrm{AO}-\mathrm{H}_{2} \mathrm{O}_{2}$ under UVA irradiation (AO- $\mathrm{H}_{2} \mathrm{O}_{2}$-UVA), EF and PEF processes for degrading SMX. The influence of current density, initial SMX concentration and initial $\mathrm{Fe}^{2+}$ concentration on the total organic carbon (TOC) reduction rate and mineralization current efficiency (MCE) on the SMX degradation in the PEF process was explored. The antibiotic decay was followed by high performance liquid chromatography (HPLC), and its aromatic intermediates were identified by HPLC-mass spectrometry (HPLC-MS), while the short-chain organic acids were detected by ion-exclusion chromatography. The quantities of $\mathrm{NO}_{3}{ }^{-}$ and $\mathrm{NH}_{4}{ }^{+}$were also determined to evaluate the extent to which the corresponding mineralization process took place.

\section{Materials and methods}

\subsection{Chemicals and analyses}

Sulfamethoxazole (98\%) was obtained from Wako. The physicochemical properties and possible cleavage positions of SMX are presented in Table 1 [46]. Iron(II) sulphate heptahydrate (99\%, Wako) and sodium sulphate (anhydrous, 99\%, Wako) were used as the catalyst and supporting electrolyte, respectively. All solutions were prepared with ultra-pure water obtained from a Milipore AutoPure WT101UV system (Millipore S. A. S., Molsheim, France) with a resistivity of $18.2 \mathrm{M} \Omega \mathrm{cm}$ at $25^{\circ} \mathrm{C}$. Acetonitrile and the distilled water used as the solvents for the liquid chromatography mobile phase were of HPLC grade, and were obtained from Wako. Pressurized oxygen gas (99.9\%) was used to saturate the solutions.

\subsection{Procedures and equipments}

Experiments were conducted at room temperature in an undivided, two-electrode quartz cell containing a $125-\mathrm{mL}$ solution stirred with a magnetic bar, as shown in Fig. 1 . The anode was a $4 \mathrm{~cm} \times 4 \mathrm{~cm} \mathrm{RuO} / 2 / \mathrm{Ti}$ mesh. The cathode, a $16 \mathrm{~cm}^{2} \mathrm{ACF}$ felt, was presaturated with SMX solution for $12 \mathrm{~h}$ to preclude a decrease in TOC due to SMX adsorption on the ACF felt. Pure $\mathrm{O}_{2}$ was fed into the solution at $100 \mathrm{~mL} \mathrm{~min}^{-1}$, and prior to the electrolysis, $\mathrm{O}_{2}$ was bubbled through the aqueous solutions for $30 \mathrm{~min}$. AO degradations (without $\mathrm{H}_{2} \mathrm{O}_{2}$ in solution) were performed using a $16 \mathrm{~cm}^{2} \mathrm{RuO}_{2} / \mathrm{Ti}$ mesh as the anode and a $16 \mathrm{~cm}^{2} \mathrm{RuO}_{2} / \mathrm{Ti}$ mesh as the cathode. AO$\mathrm{H}_{2} \mathrm{O}_{2}, \mathrm{EF}$, and PEF treatments were then carried out using a $16 \mathrm{~cm}^{2}$ ACF cathode, fed with pure $\mathrm{O}_{2}$ at $100 \mathrm{~mL} \mathrm{~min}^{-1}$. PEF trials became operative when the solution was irradiated with ultraviolet lamps (Handy UV Lamp SLUV-8, 254/365 nm, As One Co. Ltd., Japan). The lamp was placed parallel to the side of the cell, at a distance of $5 \mathrm{~cm}$ from the solution, providing the solution with a photoionization energy input of $1407 \mu \mathrm{W} \mathrm{cm}{ }^{-2}$ (this data is obtained from the Instruction Manual). 


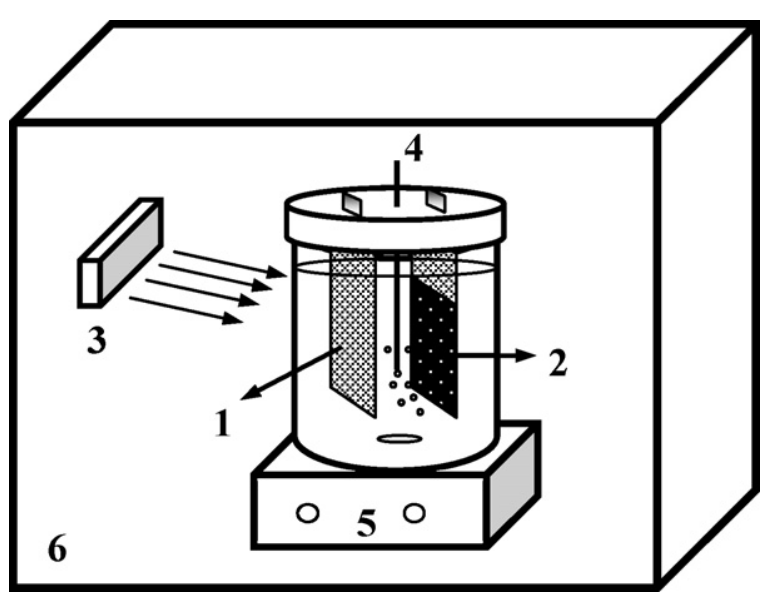

Fig. 1. Experimental set-up of the photoelectro-Fenton (PEF) reactor. $1, \mathrm{RuO}_{2} / \mathrm{Ti}$ anode; 2 , ACF cathode; 3 , UVA lamp; $4, \mathrm{O}_{2}$ in pipe; 5 , magnetic stirrer; and 6 , dark box.

A catalytic quantity of ferrous ion was introduced into the solution before the beginning of electrolysis. The current passing through the solution was measured and displayed continuously throughout electrolysis using a regulated digital DC power supply (AD-8735, A\&D Co., Tokyo, Japan). Prior to the reaction, the $\mathrm{pH}$ of the initial solutions was set at 3.0 by the addition of $0.1 \mathrm{M} \mathrm{H}_{2} \mathrm{SO}_{4}$. HM-30 V model (TOA Electrochemical Measuring Instructments, Tokyo, Japan) pH meter was employed for $\mathrm{pH}$ measurements. The ionic strength was maintained at a constant of $0.05 \mathrm{M}$ by the addition of $\mathrm{Na}_{2} \mathrm{SO}_{4}$. The $200 \mathrm{mg} \mathrm{L}^{-1} \mathrm{SMX}$ simulated wastewater was degraded by the PEF process in an aqueous medium containing $0.05 \mathrm{M} \mathrm{Na}_{2} \mathrm{SO}_{4}$ and $1 \mathrm{mM} \mathrm{Fe}^{2+}$. The current was maintained at a constant $0.36 \mathrm{~A}$.

\subsection{Chemical analysis}

Before the analysis of the treated solutions, all samples were filtered through hydrophilic PTFE filters of $0.45 \mu \mathrm{m}$ purchased from Millipore. The total organic carbon (TOC) content was measured using a Shimadzu model TOC 5000A TOC analyzer, equipped with an autosampler (ASI 5000A) (Shimadzu Co., Kyoto, Japan). $\mathrm{H}_{2} \mathrm{O}_{2}$ concentrations were determined spectrophotometrically by the iodide method with a HACH DR/4000U UV-visible spectrophotometer (HACH Co., USA) at $\lambda=352 \mathrm{~nm}\left(\varepsilon=26,400 \mathrm{M}^{-1} \mathrm{~cm}^{-1}\right.$, detection limit of $\left.\approx 10^{-6} \mathrm{M}[38]\right)$. Ammonium $\left(\mathrm{NH}_{4}{ }^{+}\right)$concentration in treated solutions was determined from the standard colorimetric automated phenate method with above $\mathrm{HACH}$ DR/4000U spectrophotometer. The formation of $\mathrm{NO}_{3}{ }^{-}$and $\mathrm{NO}_{2}{ }^{-}$in the PEF process was measured colorimetrically by an autoanalyser (QUAATRO; BLTEC, Tokyo, Japan).

\subsection{HPLC and LC-MS analysis}

\subsubsection{HPLC analysis of SMX decay and carboxylic acids formation}

The extent of the decay of SMX concentration during the treatment was quantified using an Agilent HPLC 1200 Series system equipped with a diode array detector set at $270 \mathrm{~nm}$ and an Xterra ${ }^{\circledR}$ MS C18 $5 \mu \mathrm{m} 150 \mathrm{~mm} \times 2.1 \mathrm{~mm}$ analytical column (Waters Co., USA). The mobile phase consisted of 80:20 water (adjusted to $\mathrm{pH}=3.0$ with phosphoric acid)/acetonitrile at a flow rate of $0.5 \mathrm{~mL} \mathrm{~min}^{-1}$. The injection volume was $10 \mu \mathrm{L}$. SMX had a retention time of 3.0 min under these conditions. Generated short-chain carboxylic acids were identified and quantitatively followed by ion-exclusion chromatography using the above HPLC fitted with a Bio-Rad Aminex ${ }^{\circledR}$ HPX-87H column $(300 \mathrm{~mm} \times 7.8 \mathrm{~mm}$ (i.d.)) at $35^{\circ} \mathrm{C}$ and selecting the photodiode detector at $\lambda=210 \mathrm{~nm}$. A mobile phase of $4 \mathrm{mM} \mathrm{H}_{2} \mathrm{SO}_{4}$ solution formed at $0.6 \mathrm{~mL} \mathrm{~min}^{-1}$.

\subsubsection{The $L C-M S$ analysis of reaction product mixtures}

Organic intermediates were analyzed on a Waters Alliance 2695/ZQ4000 HPLC-MS spectrometer equipped with a Waters XTerra ${ }^{\circledR} \mathrm{MS} \mathrm{C}_{18}$ column $(150 \mathrm{~mm} \times 2.1 \mathrm{~mm}$ i.d., $5 \mu \mathrm{m}$ particle size), and a thermostat $\left(30^{\circ} \mathrm{C}\right)$. MS analyses were conducted using positive mode electrospray ionization (ESI+) over a mass scan range of $80-500 \mathrm{~m} / \mathrm{z}$ under the following conditions: capillary $3.5 \mathrm{kV}$, cone $25 \mathrm{~V}$, extractor $3 \mathrm{~V}$, RF lens $0.3 \mathrm{~V}$, source temp. $120^{\circ} \mathrm{C}$, dissolvation temp. $300{ }^{\circ} \mathrm{C}$. Dissolvation and cone gas flow were set to $300 \mathrm{Lh}^{-1}$ and $50 \mathrm{~L} \mathrm{~h}^{-1}$, respectively. The volume of injection was $10 \mu \mathrm{L}$. A and $B$ mobile phases were acetonitrile and water with $0.1 \%$ formic acid, respectively, at a flow rate of $0.2 \mathrm{~mL} \mathrm{~min}^{-1}$. A linear gradient progressed from $10 \% \mathrm{~A}$ (initial conditions) constant for $5 \mathrm{~min}$, followed by a linear gradient to $100 \% \mathrm{~A}$ in $50 \mathrm{~min}$, after which the mobilephase composition was maintained at $100 \%$ A for 3 min [47]. Under these conditions, the retention time of SMX was $16.7 \mathrm{~min}$.

\subsection{Mineralization current efficiency (MCE)}

This change in the oxidative ability with electrolysis time can be better explained from its mineralization current efficiency (MCE) [34,36]:

$\mathrm{MCE}=\frac{\Delta(\mathrm{TOC})_{\exp }}{\Delta(\mathrm{TOC})_{\text {theo }}} \times 100$

where $\Delta(\text { TOC })_{\exp }$ is the experimental TOC decay $\left([\mathrm{TOC}]_{0}-[\mathrm{TOC}]_{t}\right)$ and $\Delta(\mathrm{TOC})_{\text {theo }}$ is the theoretically calculated TOC decay, assuming that the applied electrical charge (= current $\times$ time) is completely used for the mineralization of SMX into $\mathrm{CO}_{2}, \mathrm{H}_{2} \mathrm{O}, \mathrm{NH}_{4}{ }^{+}$and $\mathrm{SO}_{4}{ }^{2-}$ as follows:

$$
\begin{aligned}
& \mathrm{C}_{10} \mathrm{H}_{11} \mathrm{~N}_{3} \mathrm{O}_{3} \mathrm{~S}+21 \mathrm{H}_{2} \mathrm{O} \rightarrow 10 \mathrm{CO}_{2}+\mathrm{SO}_{4}{ }^{2-}+3 \mathrm{NH}_{4}{ }^{+}+41 \mathrm{H}^{+} \\
& \quad+42 \mathrm{e}^{-}
\end{aligned}
$$

which involves the consumption of $42 \mathrm{~F} \mathrm{~mol}^{-1}$ of SMX.

\section{Results and discussion}

\subsection{Hydrogen peroxide electrogeneration in the PEF process}

The ability of the electrolytic system to accumulate hydrogen peroxide supplied by the ACF felt cathode from reaction (1) was studied by determining the concentration of accumulated $\mathrm{H}_{2} \mathrm{O}_{2}$. Several electrolyses of $0.05 \mathrm{M} \mathrm{Na}_{2} \mathrm{SO}_{4}$ and initial pH 3.0 solutions were carried out in the absence of $\mathrm{Fe}^{2+}$ and UVA. These trials were performed with an ACF felt cathode at different current intensities, as is shown in Fig. 2. A progressive increase of $\mathrm{H}_{2} \mathrm{O}_{2}$ concentration was detected during electrolysis as the current increased from $0.12 \mathrm{~A}$ to $0.50 \mathrm{~A}$ in the initial $120 \mathrm{~min}$ of electrolysis, after which the $\mathrm{H}_{2} \mathrm{O}_{2}$ concentrations obtained were ca.321, 609, 759 and $765 \mu \mathrm{M} \mathrm{H}_{2} \mathrm{O}_{2}$ at $0.12,0.24,0.36$ and $0.50 \mathrm{~A}$, respectively. The $\mathrm{H}_{2} \mathrm{O}_{2}$ concentrations did not increase linearly with time. Rather, after approximately $30 \mathrm{~min}$, the solutions reached a steadystate concentration, and then they remained almost constant. Even though no $\mathrm{Fe}(\mathrm{II})$ was deliberately added to the cell, a mechanism for the decomposition of the hydrogen peroxide caused $\mathrm{H}_{2} \mathrm{O}_{2}$ to undergo chemical decomposition to $\mathrm{O}_{2}$ either on the anode (heterogeneous process) or in the medium (homogeneous process) (Eq. (10)) $[34,38]$. As well as this, $\mathrm{H}_{2} \mathrm{O}_{2}$ was also able to be anodically oxidized to yield intermediate $\mathrm{HO}_{2}$ radicals (Eqs. (11) and (12)). In the steady state, $\mathrm{H}_{2} \mathrm{O}_{2}$ was electrogenerated and simultaneously destroyed in the system at the same rate. It was found from Fig. 2 


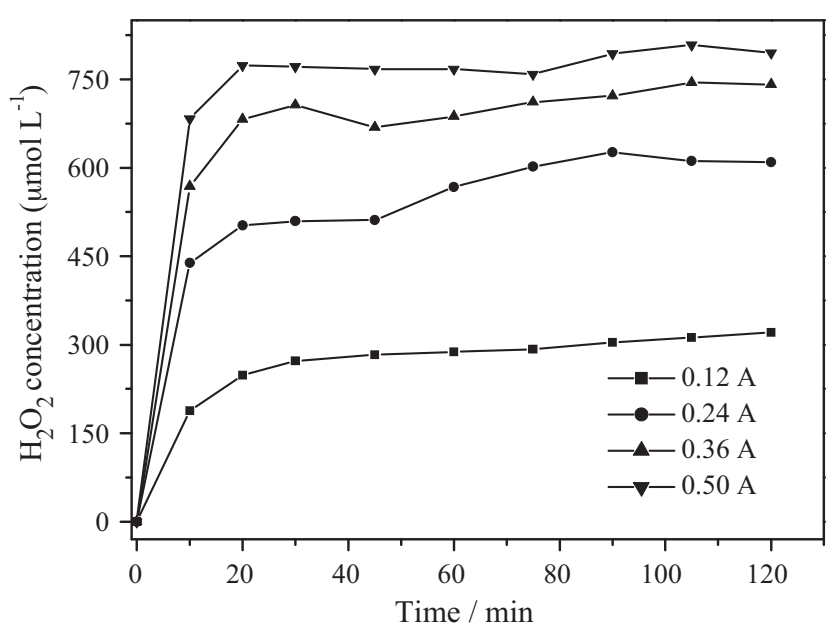

Fig. 2. Electrogeneration of $\mathrm{H}_{2} \mathrm{O}_{2}$ during the electrolysis of $0.05 \mathrm{M} \mathrm{Na}_{2} \mathrm{SO}_{4}$ and initial pH 3.0 solutions in the absence of $\mathrm{Fe}^{2+}$ and UVA with ACF cathode.

that the stable $\mathrm{H}_{2} \mathrm{O}_{2}$ concentration increased as the current density increased in the range from $0.12 \mathrm{~A}$ to $0.50 \mathrm{~A}$, while the strong reaction of $\mathrm{H}_{2} \mathrm{O}_{2}$ anodically oxidizing at the anode at $0.50 \mathrm{~A}$ meant almost negligible increases in the $\mathrm{H}_{2} \mathrm{O}_{2}$ concentration. This can be explained by the following:

$\mathrm{H}_{2} \mathrm{O}_{2} \rightarrow \mathrm{H}_{2} \mathrm{O}+1 / 2 \mathrm{O}_{2}$

$\mathrm{H}_{2} \mathrm{O}_{2} \rightarrow \mathrm{HO}_{2}^{\bullet}+\mathrm{H}^{+}+\mathrm{e}^{-}$

$\mathrm{HO}_{2} \bullet \mathrm{O}_{2}+\mathrm{H}^{+}+\mathrm{e}^{-}$

\subsection{Comparative degradation behavior}

A first series of trials was carried out by electrolyzing $200 \mathrm{mg} \mathrm{L}^{-1}$ SMX at $\mathrm{pH} 3.0$ and $0.36 \mathrm{~A}$ for $6 \mathrm{~h}$ to clarify the comparative oxidation power of the EAOPs tested. The EF and PEF treatments operated with a $1.0 \mathrm{mM} \mathrm{Fe}^{2+}$ catalyst. Fig. 3(a) summarizes the results of the TOC decay corresponding to the destruction of $200 \mathrm{mg} \mathrm{L}^{-1}$ of SMX solution at $\mathrm{pH} 3.0$ due to ACF adsorption, $\mathrm{AO}, \mathrm{AO}-\mathrm{H}_{2} \mathrm{O}_{2}, \mathrm{AO}-\mathrm{H}_{2} \mathrm{O}_{2}$ UVA, EF and the PEF conditions, respectively. The applied current was a constant $0.36 \mathrm{~A}$. As could be seen, the use of ACF felt adsorption alone on SMX meant the removal of SMX was limited to 5\% after $360 \mathrm{~min}$. This low adsorption can be attributed to the presaturation of the ACF felt before the experiments. Similarly, AO alone resulted in less than a $25 \%$ reduction in TOC. In these experiments, we used an $\mathrm{RuO}_{2} / \mathrm{Ti}$ anode, a low oxidation power anode characterized by a strong interaction between the electrode and $\bullet \mathrm{OH}$, resulting in high electrochemical activity for the evolution of oxygen and low chemical reactivity for organic oxidation. In this strong interaction, the absorbed $\cdot \mathrm{OH}$ interacts with the anode, resulting in a transition of the oxygen from ${ }^{\bullet} \mathrm{OH}$ to the anode surface, which forms a higher oxide which then selectively oxidizes organic pollutants via the surface redox couple [48]. When $\mathrm{AO}-\mathrm{H}_{2} \mathrm{O}_{2}$ was used, the TOC degradation was a little faster, with $28 \%$ of the TOC decayed. In this reaction, intermediates are slowly mineralized by the $\bullet \mathrm{OH}$ generated from the heterogeneous or homogeneous reactions between the ruthenium electrode $\left(\mathrm{RuO}_{2} / \mathrm{Ti}\right)$ and $\mathrm{H}_{2} \mathrm{O}_{2}$ in accordance with the classic interpretation of the Haber and Weiss cycle [48-50]. The decomposition rate of SMX in the AO- $\mathrm{H}_{2} \mathrm{O}_{2}$-UVA process was significantly better, with $36 \%$ of the TOC removed, and this can be attributed to the additional degradation from UVA irradiation. In the EF process, TOC was rapidly reduced by as much as $63 \%$ after 360 min of electrolysis. This can be explained by the fast homogeneous reaction of organics with the great amount of - OH generated from reaction (2), which then nonselectively oxi-
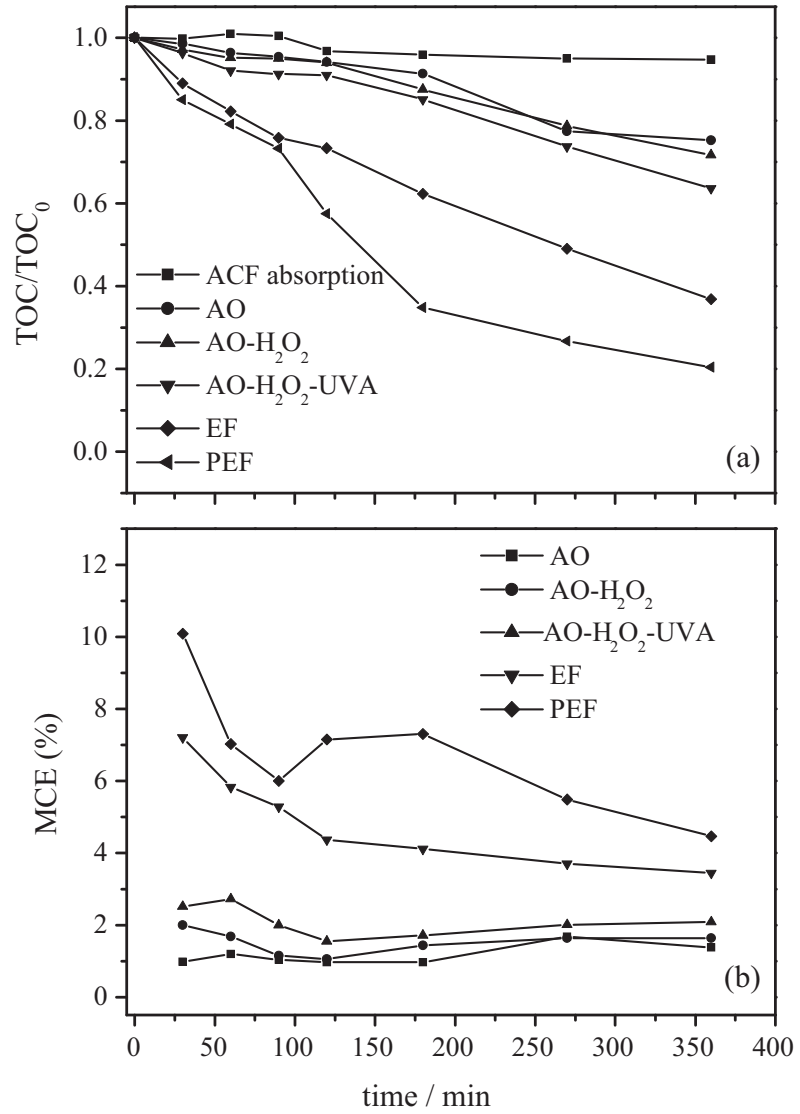

Fig. 3. (a) TOC reduction as a function of treatment time for the ACF adsorption, $A O$, AO- $\mathrm{H}_{2} \mathrm{O}_{2}, A O-\mathrm{H}_{2} \mathrm{O}_{2}-\mathrm{UVA}$, EF and PEF conditions (b) Change of the mineralization current efficiency (MCE).

dized most of the products remaining in the solution. In contrast, a significant acceleration in the PEF method with $1 \mathrm{mM} \mathrm{Fe}^{2+}$ had an even higher oxidative ability, with $80 \%$ of the TOC of solution reduced after $360 \mathrm{~min}$ of electrolysis. The faster TOC removal in the PEF process is thought to result in the generation of more - $\mathrm{OH}$ due to the fast photodecomposition of $\mathrm{Fe}(\mathrm{III})$-oxalate complexes by UV light and the additional photo-reduction of $\mathrm{Fe}(\mathrm{OH})^{2+}$ species according to reactions (5) and (6), and this would mean an additional supply of $\mathrm{Fe}^{2+}$ and ${ }^{\bullet} \mathrm{OH}$ for the mineralization of SMX [41].

In order to confirm the oxidation power of the different process, the MCE values for all the trials were calculated from Eq. (8), and are shown in Fig. 3(b). As expected, a maximum efficiency of about 10\% for PEF, $7 \%$ for $\mathrm{EF}, 3 \%$ for $\mathrm{AO}-\mathrm{H}_{2} \mathrm{O}_{2}-\mathrm{UVA}$, $2 \%$ for $\mathrm{AO}-\mathrm{H}_{2} \mathrm{O}_{2}$ and $1 \%$ for $\mathrm{AO}$ was found at the 30 min mark. The MCE follows the same trend as the relative oxidation power of the methods tested, increasing in the sequence: $\mathrm{AO}<\mathrm{AO}-\mathrm{H}_{2} \mathrm{O}_{2}<\mathrm{AO}-\mathrm{H}_{2} \mathrm{O}_{2}-\mathrm{UVA}<\mathrm{EF}<\mathrm{PEF}$. The above findings suggest that the fastest decontamination of acidic SMX wastewaters is achieved by the PEF process.

\subsection{Optimization of experimental conditions}

\subsubsection{Effect of applied current}

The influence of applied current on the degradative behavior was examined by electrolyzing a $200 \mathrm{mg} \mathrm{L}^{-1} \mathrm{SMX}$ solution of $\mathrm{pH}$ 3.0 at $0.12 \mathrm{~A}, 0.24 \mathrm{~A}, 0.36 \mathrm{~A}$ and $0.50 \mathrm{~A}$. As shown in Fig. 4(a), 53\% of TOC was removed at $0.12 \mathrm{~A}$ after $360 \mathrm{~min}$, while at $0.24,0.36$ and $0.50 \mathrm{~A}, \mathrm{TOC}$ removal was $66 \%, 80 \%$ and $67 \%$, respectively. It was found that increasing the current density in the range $0.12-0.36 \mathrm{~A}$ quickens the pace of mineralization in the PEF process. Increasing 

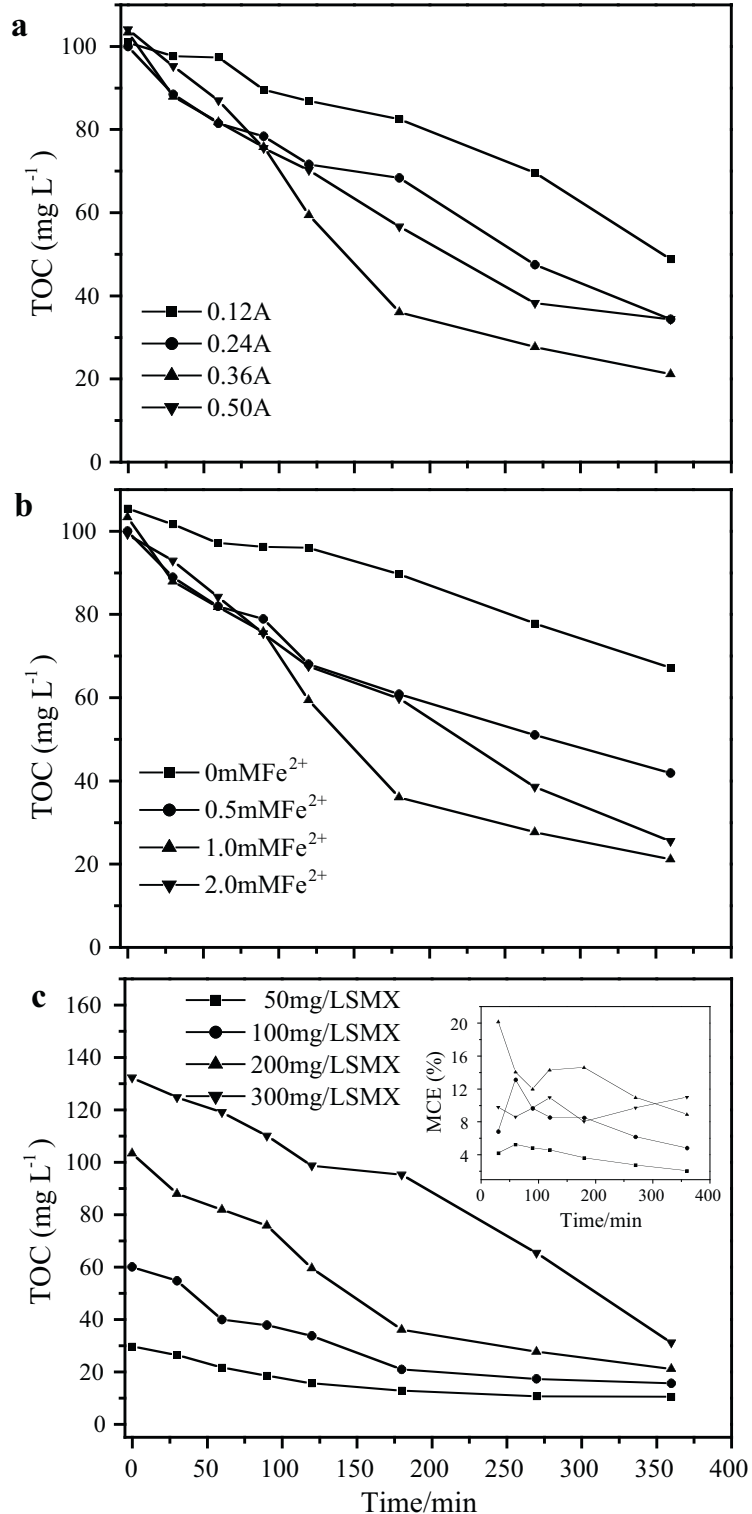

Fig. 4. Effect of (a) applied current (b) $\mathrm{Fe}^{2+}$ concentration and (c) initial SMX concentration on TOC removal decay during the PEF treatment of $125 \mathrm{~mL}^{\circ} 200 \mathrm{mg} \mathrm{L}^{-1}$ SMX solutions.

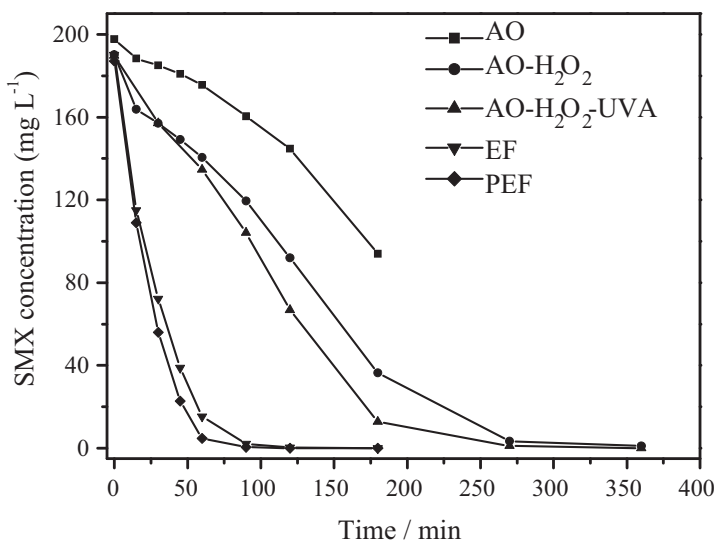

Fig. 5. Decay of SMX concentration with electrolysis time during the degradation of $125 \mathrm{~mL}$ of a $200 \mathrm{mg} \mathrm{L}^{-1} \mathrm{SMX}$ solution and $0.05 \mathrm{M} \mathrm{Na}_{2} \mathrm{SO}_{4}$ of $\mathrm{pH} 3$ by $\mathrm{AO}, \mathrm{AO}-\mathrm{H}_{2} \mathrm{O}_{2}$, $\mathrm{AO}-\mathrm{H}_{2} \mathrm{O}_{2}$-UVA, EF and PEF process at $\mathrm{pH} 3.0$ and $0.36 \mathrm{~A}$.
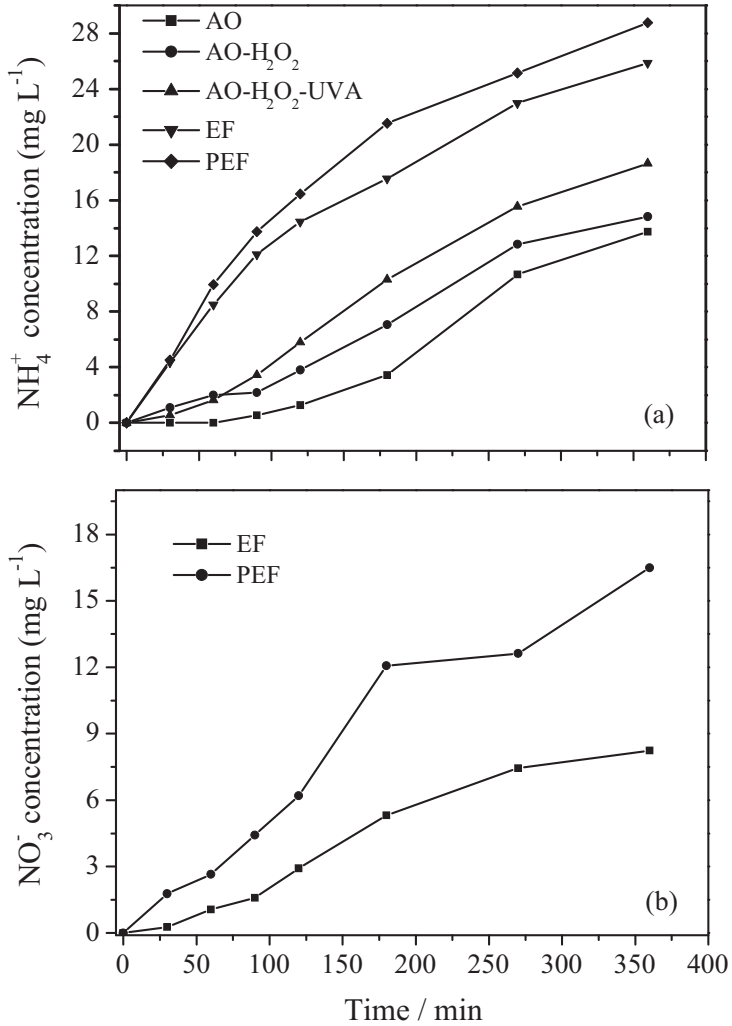

Fig. 6. (a) Concentration of $\mathrm{NH}_{4}^{+}$ions accumulated in the medium vs. electrolysis time during the treatments of $\mathrm{AO}, \mathrm{AO}-\mathrm{H}_{2} \mathrm{O}_{2}, \mathrm{AO}-\mathrm{H}_{2} \mathrm{O}_{2}-\mathrm{UVA}, \mathrm{EF}$ and PEF process. (b) $\mathrm{NO}_{3}{ }^{-}$concentration accumulated in the $\mathrm{EF}$ and $\mathrm{PEF}$ process was also measured ( $\mathrm{pH}$ 3.0 and $0.36 \mathrm{~A}$ ).
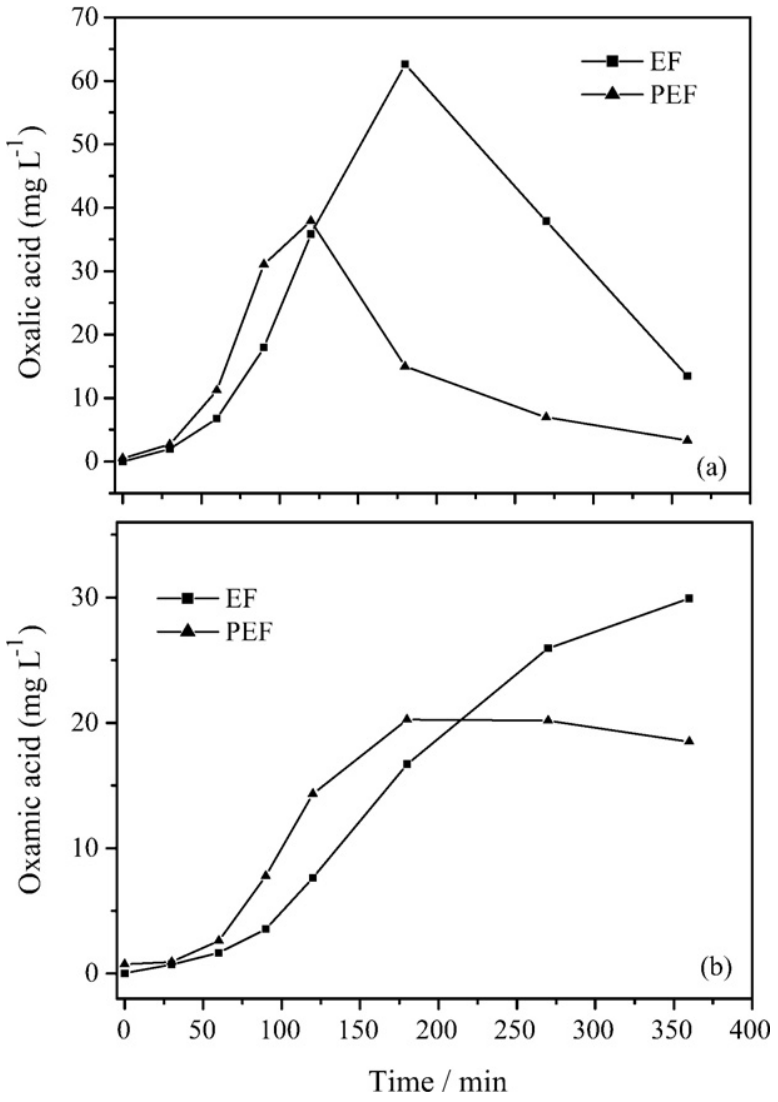

Fig. 7. Evolution of the concentration of oxalic acid and oxamic acid formed during the degradation of $200 \mathrm{mg} \mathrm{L}^{-1}$ of SMX under EF and PEF conditions. 
the current density means the SMX is removed more rapidly due to the concomitant increased production rate of $\mathrm{H}_{2} \mathrm{O}_{2}$ generated at the ACF cathode. This, in turn, enhances the generation of $\bullet \mathrm{OH}$ in the Fenton reaction since the production of $\bullet \mathrm{OH}$ in the medium is proportional to the $\mathrm{H}_{2} \mathrm{O}_{2}$ concentration, as shown in the following Eq. (13) [51]:

$[\bullet \mathrm{OH}]=\lambda\left(\frac{d[\bullet \mathrm{OH}]}{d t}\right)_{g}=\lambda k_{1}\left[\mathrm{Fe}^{2+}\right]\left[\mathrm{H}_{2} \mathrm{O}_{2}\right]$

where $k_{1}$ is the second-order rate constant $\left(\mu \mathrm{M}^{-1} \mathrm{~min}^{-1}\right)$ of reaction (2); $\lambda$ is the average life of the $\bullet \mathrm{OH}(\mathrm{min})$; and $\left[\mathrm{Fe}^{2+}\right]$ and $\left[\mathrm{H}_{2} \mathrm{O}_{2}\right]$ are the concentrations of ferrous ion $(\mu \mathrm{M})$ and hydrogen peroxide $(\mu \mathrm{M})$, respectively.

It is also true, however, that when the applied current is over $0.50 \mathrm{~A}$, the pace of mineralization slows, indicating a slower generation of oxidant $\bullet \mathrm{OH}$. One reason for this is that when the applied current is high, $\mathrm{H}_{2} \mathrm{O}_{2}$ is anodically oxidized to yield intermediate $\mathrm{HO}_{2}{ }^{\bullet}$ radicals, which are less potent than ${ }^{\bullet} \mathrm{OH}$. Another reason is that when the applied current is high, more $\mathrm{Fe}^{2+}$ in the solution is anodically oxidized to $\mathrm{Fe}^{3+}$, leading to a decrease in ${ }^{\bullet} \mathrm{OH}$ formation (see Eq. (13)) [38]. The other reason is that when the applied current is high, the dimerization of $\bullet \mathrm{OH}$ to $\mathrm{H}_{2} \mathrm{O}_{2}$ (reaction (14)) or its destruction with $\mathrm{H}_{2} \mathrm{O}_{2}$ (reactions (15)) may also reduce the efficiency of the PEF process [52].

$2 \bullet \mathrm{OH} \rightarrow \mathrm{H}_{2} \mathrm{O}_{2}$

$\bullet \mathrm{OH}+\mathrm{H}_{2} \mathrm{O}_{2} \rightarrow \mathrm{HO}_{2} \cdot \mathrm{H}_{2} \mathrm{O}$

\subsubsection{Effect of $\mathrm{Fe}^{2+}$ concentration}

Fig. 4(b) shows the results when $200 \mathrm{mg} \mathrm{L}^{-1}$ of SMX solution is treated for $360 \mathrm{~min}$ by the PEF process with $\mathrm{Fe}^{2+}$ dosing from $0 \mathrm{mM}$ to $2.0 \mathrm{mM}$ at $\mathrm{pH} 3.0$ and $0.36 \mathrm{~A}$. An obvious increase in the rate of TOC decay was observed with the addition of $\mathrm{Fe}^{2+}$ ion into the solution, suggesting that raising the initial $\mathrm{Fe}^{2+}$ concentration from $0 \mathrm{mM}$ to $1 \mathrm{mM}$ might augment TOC removal. For example, after 360 min of electrolysis, the TOC removal was $36 \%, 58 \%, 80 \%$ for 0 , 0.5 and $1 \mathrm{mM} \mathrm{Fe}^{2+}$ solution, respectively. When the $\mathrm{Fe}^{2+}$ concentration was increased to $2 \mathrm{mM}$, however, the TOC abated more slowly, with $74 \%$ of the TOC removed after 360 min of electrolysis. This is consistent with what was expected: the initial $\mathrm{Fe}^{2+}$ was rapidly transformed into $\mathrm{Fe}^{3+}$ from reaction (2), with the small catalytic amount of regenerated $\mathrm{Fe}^{2+}$ in the medium in effect regulating the continuous production of oxidizing $\bullet \mathrm{OH}$. The influence of higher $\mathrm{Fe}^{2+}$ concentration upon the degradation behavior of SMX is likely due to the percentage of ${ }^{\circ} \mathrm{OH}$ scavenged by $\mathrm{Fe}^{2+}$, as shown in Eq. (16) [38].

$\mathrm{Fe}^{2+}+\cdot \mathrm{OH} \rightarrow \mathrm{Fe}^{3+}+\mathrm{OH}^{-}$

\subsubsection{Effect of initial SMX concentration}

The effect of the initial antibiotic concentration on mineralization was studied in four concentrations of SMX solutions in the presence of $1 \mathrm{mM} \mathrm{Fe}^{2+}$ with a $\mathrm{pH}$ of 3.0 at $0.36 \mathrm{~A}$ by the PEF process. Fig. 4(c) shows the results: $77 \%$ of the TOC was removed for up to $300 \mathrm{mg} \mathrm{L}^{-1}$ of SMX within 360 min electrolysis, whereas the removal rate was $80 \%, 85 \%$ and $65 \%$ in 200,100 and $50 \mathrm{mg} \mathrm{L}^{-1} \mathrm{SMX}$ solutions, respectively. This change in the oxidative ability can be better explained from its MCE. As shown in the inset of Fig. 4(c), the MCE value usually increases when the SMX concentration is increasing. This trend is associated with a faster destruction of all pollutants, since higher concentrations of them in the medium means that they can react more rapidly with generated oxidants, mainly the $\bullet \mathrm{OH}$ produces from reactions (2), (6), (8) and (9). When the SMX concentration is $300 \mathrm{mg} \mathrm{L}^{-1}$, however, the MCE falls to a minimum value then increases over time with electrolysis. This is thought to be attributed to the proportion between the concentra-

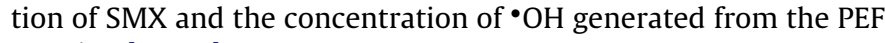
reaction $[48,53]$.

\subsection{Degradation of SMX and products time-course}

\subsubsection{SMX decay}

Several trials were made by electrolysing $200 \mathrm{mg} \mathrm{L}^{-1} \mathrm{SMX}$ solutions at $\mathrm{pH} 3.0$ by $\mathrm{AO}, \mathrm{AO}-\mathrm{H}_{2} \mathrm{O}_{2}, \mathrm{AO}-\mathrm{H}_{2} \mathrm{O}_{2}$-UVA, as well as under $\mathrm{EF}$ and PEF conditions at $0.36 \mathrm{~A}$ to clarify the oxidizing ability of the different processes. As can be seen in Fig. 5, SMX is degraded at the lowest initial rate only when AO was used, but after $180 \mathrm{~min}$ electrolysis, only about 53\% SMX was removed. SMX decay in the $\mathrm{AO}-\mathrm{H}_{2} \mathrm{O}_{2}$ experiment was extensive, with $81 \%$ SMX removed within $180 \mathrm{~min}$, and almost total degradation after $360 \mathrm{~min}$ electrolysis. The increase in the degradation rate of SMX in $\mathrm{AO}-\mathrm{H}_{2} \mathrm{O}_{2}$ is due to the homogeneous reaction with the $\bullet \mathrm{OH}$ formed. With UVA irradiation, SMX degradation was at $93 \%$ after $180 \mathrm{~min}$ electrolysis in $\mathrm{AO}-\mathrm{H}_{2} \mathrm{O}_{2}$-UVA, and total degradation happens after 270 min. SMX degraded remarkably quickly under both EF and PEF conditions, with total SMX removal possible after only $90 \mathrm{~min}$ of electrolysis. In the EF process, the fast abatement of SMX is largely attributable to the behavior of $\bullet \mathrm{OH}$ on SMX from the Fenton reaction. In the PEF process, the SMX decays even faster than in EF process due to the production of additional $\bullet \mathrm{OH}$ from the photoreduction of $\mathrm{Fe}(\mathrm{OH})^{2+}$ and the production of additional $\mathrm{Fe}^{2+}$ from the photolysis of $\mathrm{Fe}(\mathrm{III})$ complexes with carboxylic acids under UVA irradiation [41]. It is worth noting that the photodegradation of SMX may also take place in the PEF process, thus enhancing the SMX removal [47].

\subsubsection{Intermediate products in electrochemical experiments}

3.4.2.1. Evolution of inorganic intermediates. The total mineralization of an organic compound containing heteroatoms tends to be accompanied by the formation of carbon dioxide and inorganic ions. While the sulphur atom is recovered as sulphate $\left(\mathrm{SO}_{4}{ }^{2-}\right)$ irrespective of its initial oxidation state, nitrogen moieties in organic compounds can be transformed to either $\mathrm{NH}_{3}\left(\mathrm{NH}_{4}{ }^{+}\right.$in acidic media) and/or nitrite $\left(\mathrm{NO}_{2}{ }^{-}\right)$and nitrate $\left(\mathrm{NO}_{3}{ }^{-}\right)$ions. In this study $\mathrm{SO}_{4}{ }^{2-}$ ions were not monitored because of the supporting electrolyte $\mathrm{Na}_{2} \mathrm{SO}_{4}$ in the solution, but many authors have confirmed $\mathrm{SO}_{4}{ }^{2-}$ is the ultimate byproduct in SMX degradation [26,54]. The evolution of inorganic ions $\left(\mathrm{NH}_{4}{ }^{+}, \mathrm{NO}_{3}{ }^{-}, \mathrm{NO}_{2}{ }^{-}\right)$during the electrolyses of $200 \mathrm{mg} \mathrm{L}^{-1} \mathrm{SMX}$ solutions at $0.36 \mathrm{~A}$ under $\mathrm{AO}, \mathrm{AO}-\mathrm{H}_{2} \mathrm{O}_{2}$, AO- $\mathrm{H}_{2} \mathrm{O}_{2}$-UVA, EF and PEF conditions was quantified. As shown in Fig. 6(a), stationary $\mathrm{NH}_{4}{ }^{+}$was detected in all cases, and faster $\mathrm{NH}_{4}{ }^{+}$ion accumulation was observed in the EF and PEF processes. After $6 \mathrm{~h}$ of electrolysis, $25.9 \mathrm{mg} \mathrm{L}^{-1}$ and $28.8 \mathrm{mg} \mathrm{L}^{-1}$ of $\mathrm{NH}_{4}^{+}$was generated in the EF and PEF processes, respectively, compared with $13.7 \mathrm{mg} \mathrm{L}^{-1}, 14.8 \mathrm{mg} \mathrm{L}^{-1}, 18.6 \mathrm{mg} \mathrm{L}^{-1}$ of $\mathrm{NH}_{4}{ }^{+}$accumulation in the $\mathrm{AO}, \mathrm{AO}-\mathrm{H}_{2} \mathrm{O}_{2}$ and $\mathrm{AO}-\mathrm{H}_{2} \mathrm{O}_{2}$-UVA processes, respectively. These results can be explained by the more rapid destruction of SMX by the ${ }^{\bullet} \mathrm{OH}$ generated from the Fenton reaction in the EF and PEF processes. In addition, $\mathrm{NO}_{3}{ }^{-}$was also detected in the $\mathrm{EF}$ and PEF electrolysed solutions (no $\mathrm{NO}_{2}{ }^{-}$ion was detected) (Fig. 6 (b)). $\mathrm{A} \mathrm{NO}_{3}{ }^{-}$concentration up to ca. $16.5 \mathrm{mg} \mathrm{L}^{-1}$ was detected in solutions treated for $6 \mathrm{~h}$ by the PEF process, while about $8.2 \mathrm{mg} \mathrm{L}^{-1}$ of $\mathrm{NO}_{3}{ }^{-}$accumulated in the EF process. More $\mathrm{NH}_{4}{ }^{+}$was evolved in the PEF process than $\mathrm{NO}_{3}{ }^{-}$: after $6 \mathrm{~h}$ of electrolysis, $22.4 \mathrm{mg} \mathrm{L}^{-1}$ of the SMX-derived nitrogen ( $68 \%$ of initial nitrogen) was mineralized in the form of $\mathrm{NH}_{4}{ }^{+}$ions, while only $3.7 \mathrm{mg} \mathrm{L}^{-1}$ of the SMX-derived nitrogen (11\% of initial nitrogen) was mineralized in the form of $\mathrm{NO}_{3}$ - ions. The results indicate the aromatic amino group of SMX is a primary site for ${ }^{\bullet} \mathrm{OH}$ attack, with the initial nitrogen of SMX progressively being converted into $\mathrm{NH}_{4}{ }^{+}$ion. Different quantities of $\mathrm{NO}_{2}{ }^{-}, \mathrm{NO}_{3}{ }^{-}$and $\mathrm{NH}_{4}{ }^{+}$ions may be linked to the different features of the $\mathrm{N}$-containing structure. Nitrogroups are converted predom- 
Table 2

Identification of the SMX degradation products by LC-MS.

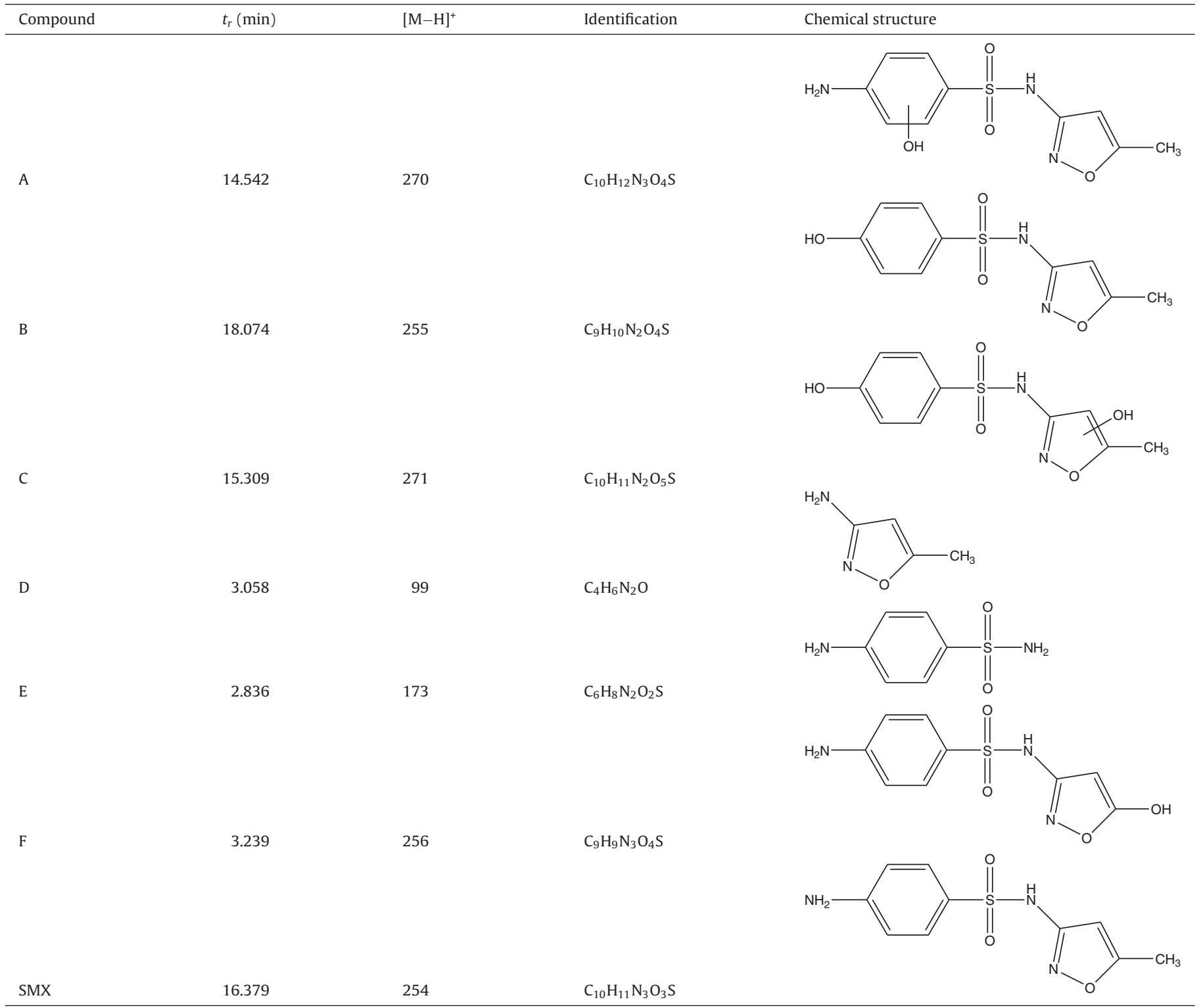

inantly to $\mathrm{NO}_{3}-$ ions, while the nitrogen in heterocyclic aromatic rings can be transformed to both $\mathrm{NH}_{4}{ }^{+}$and $\mathrm{NO}_{3}{ }^{-}$species, tertiary and quaternary nitrogen atoms are converted predominantly to $\mathrm{NH}_{4}{ }^{+}$ions [54].

3.4.2.2. Evolution of carboxylic acids. Treated solutions were analyzed by ion-exclusion HPLC chromatography to detect and follow the evolution of short-chain carboxylic acids generated during the EF and PEF mineralization process. These chromatograms exhibited peaks related to oxalic $\left(t_{r}=6.21 \mathrm{~min}\right)$, maleic $\left(t_{r}=7.91 \mathrm{~min}\right)$, oxamic $\left(t_{r}=8.56 \mathrm{~min}\right)$, formic $\left(t_{r}=12.86 \mathrm{~min}\right)$ and acetic $\left(t_{r}=14.09 \mathrm{~min}\right)$ acids. Oxalic and oxamic acids were the most persistent carboxylic acids. Fig. 7(a) shows the continuous accumulation of oxalic acid in the EF and PEF process. In the EF process, the concentration of oxalic acid increases up to $62 \mathrm{mg} \mathrm{L}^{-1}$ after $180 \mathrm{~min}$ of electrolysis at $0.36 \mathrm{~A}$, then it was slowly destroyed, with $13.5 \mathrm{mg} \mathrm{L}^{-1}$ remaining in the treated solution after $6 \mathrm{~h}$ of electrolysis. In the EF process, both uncomplexed oxalic and $\mathrm{Fe}^{2+}$-oxalate complexes are formed. Oxalic acid is directly oxidized to $\mathrm{CO}_{2}$ by ${ }^{\circ} \mathrm{OH}$ at slow rate (the absolute rate constant between ${ }^{\circ} \mathrm{OH}$ and oxalic acid is $1.6 \times 10^{6} \mathrm{M}^{-1} \mathrm{~s}^{-1}$
[55]). The oxidation of these complexes by ${ }^{\bullet} \mathrm{OH}$ proceeds according to the following reaction:

$\left(\mathrm{Fe}\left(\mathrm{C}_{2} \mathrm{O}_{4}\right)_{n}\right)^{(2-2 n)}+3 \cdot \mathrm{OH} \rightarrow 2 \mathrm{CO}_{2}+(n-1)\left(\mathrm{C}_{2} \mathrm{O}_{4}\right)^{2-}+\mathrm{Fe}^{3+}+3 \mathrm{OH}^{-}$

where at $\mathrm{pH} 3.0$, the predominant complex is given by $n=1$. Oxalate complexes are oxidized to $\mathrm{CO}_{2}$ with the $\mathrm{Fe}^{3}$ produced quickly reduced to $\mathrm{Fe}^{2+}$ again, making it possible for more $\mathrm{Fe}^{2+}$-oxalate complexes to be formed in addition to the $\cdot \mathrm{OH}$ from reaction (2) [55]. In contrast, in the PEF process, the oxalic acid content increased until a maximum value of $37 \mathrm{mg} \mathrm{L}^{-1}$ at $120 \mathrm{~min}$, then it was destroyed quickly, and after 360 min electrolysis, only $3.3 \mathrm{mg} \mathrm{L}^{-1}$ was present in the treated solution. This is due to the photocatalytic action of UV leading to the rapid mineralization of the $\mathrm{Fe}(\mathrm{III})$-oxalate complexes formed in the solution being treated by the PEF process (Eq. (6)) [32,34,36,37,41].

In the PEF process, oxamic acid concentration increases and attains a steady value near $20 \mathrm{mg} \mathrm{L}^{-1}$ from 180 to $270 \mathrm{~min}$, before dropping slightly to ca. $18 \mathrm{mg} \mathrm{L}^{-1}$ at $360 \mathrm{~min}$, while in the EF process oxamic acid increased continuously with up to $30 \mathrm{mg} \mathrm{L}^{-1}$ obtained after 360 min electrolysis (see Fig. 7). Much more oxamic acid is 


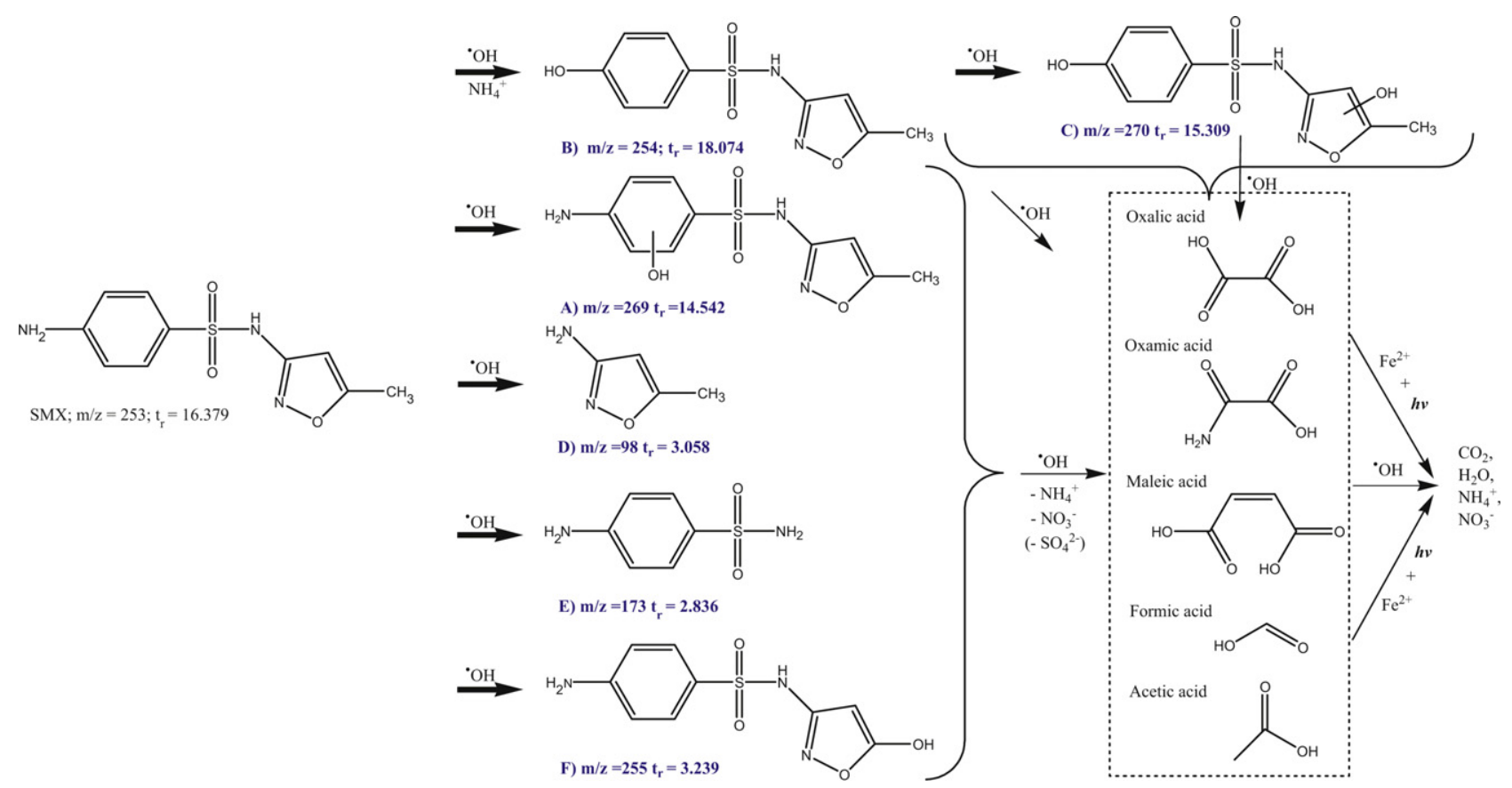

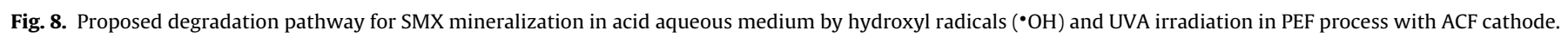

accumulated in the EF process than in the PEF process, which is due to oxamic acid is attacked poorly by ${ }^{\bullet} \mathrm{OH}$ in the EF process and UV irradiation can enhances its degradation in the PEF process [56-58].

3.4.2.3. Evolution of aromatic intermediates and SMX degradation pathway. In order to identify the intermediates in the solution and thus determine a probable reaction pathway, a mass spectroscopy study was carried out. The intermediates during SMX degradation in the PEF process were identified by LC-MS by the peaks formed, and the molecular structure of SMX is reported in Table 1. Six intermediate compounds were identified, as shown in Table 2. Product A, with an $[\mathrm{M}+\mathrm{H}]^{+}$of 270 , can be attributed to the addition of 16 mass units to the parent peak, which is consistent with the addition an $\cdot \mathrm{OH}$ to the SMX structure in different positions to yield monohydroxylated derivatives. The best-fit formula was $\mathrm{C}_{10} \mathrm{H}_{12} \mathrm{~N}_{3} \mathrm{O}_{4} \mathrm{~S}$ (a protonated molecule) $[15,24,47]$. The fragment $m / z 156$ was missing, and the ion fragment at $m / z 172\left[\mathrm{C}_{6} \mathrm{H}_{6} \mathrm{NO}_{3} \mathrm{~S}\right]$, together with those at $m / z 108$ and $m / z 99$, appeared in the SMX spectrum as well as in most of the transformation products, indicating that the attack of $\bullet \mathrm{OH}$ occurred on the benzene ring.

The intermediate $\mathrm{B}$ at $[\mathrm{M}+\mathrm{H}]^{+} 255$ mass units can be attributed to the substitution of the amine group by ${ }^{\bullet} \mathrm{OH}$ radical attack on the aniline ring ( $\beta$-cleavage, Table 1 ), forming a hydroxylated structure and releasing $\mathrm{NH}_{4}{ }^{+}$. Intermediate $\mathrm{C}$ at $[\mathrm{M}+\mathrm{H}]^{+} 271$ is the hydroxylated compound of intermediate $\mathrm{B}$, the best-fit formula for which was $\mathrm{C}_{10} \mathrm{H}_{12} \mathrm{~N}_{2} \mathrm{O}_{5} \mathrm{~S}$ (a protonated molecule), which results from the addition of $\bullet \mathrm{OH}$ on the isoxazole ring of Intermediate $\mathrm{B}$. Intermediate $\mathrm{D}$ was identified as 3-amino-5-methylisoxazole (AMI) with $m / z=99$ for $[\mathrm{M}+\mathrm{H}]^{+}[1,15,24,47]$ originated by the cleavage of the $\delta$-position. Intermediate $\mathrm{E}$ at $[\mathrm{M}+\mathrm{H}]^{+} 173$ mass units was identified as sulfanilamide $\left(\mathrm{C}_{6} \mathrm{H}_{8} \mathrm{~N}_{2} \mathrm{O}_{2} \mathrm{~S}\right)$ as a results of $\gamma$-cleavage, which was an important intermediate in the photocatalysis [17], solar photoFenton [24], photolysis [46] and ozonation [59,60] processes during $\mathrm{SMX}$ degradation. Intermediate $\mathrm{F}$ at $[\mathrm{M}+\mathrm{H}]^{+} 256$ mass units can be attributed to the substitution of the methyl group by ${ }^{\bullet} \mathrm{OH}$ radical attack on the isoxazole ring, resulting in the formation of a hydroxylated structure. This ion fragment $\mathrm{m} / z 156$ suggests that the initial degradation of SMX was due to the attack of ${ }^{\bullet} \mathrm{OH}$ radicals on the isoxazole ring.
As a result of these analyses, a reaction pathway for the complete mineralization of SMX with ${ }^{\bullet} \mathrm{OH}$ as the main oxidant is proposed in Fig. 8 . The first oxidation step of $\mathrm{SMX}$ is the attack by ${ }^{\bullet} \mathrm{OH}$ nonselectively at different sites of the SMX molecule, resulting in the formation of hydroxylated derivatives, which are oxidized further by $\bullet \mathrm{OH}$ as additional byproducts are released. The overall mineralization of SMX is accompanied by the release of $\mathrm{SO}_{4}{ }^{2-}, \mathrm{NH}_{4}{ }^{+}$, and $\mathrm{NO}_{3}{ }^{-}$ions, with the uncomplexed oxalic acids formed being destroyed by $\bullet \mathrm{OH}$, and the complexed $\mathrm{Fe}^{3+}$-oxalate being rapidly mineralized by the photocatalytic action of UVA. The release of $\mathrm{NH}_{4}{ }^{+}$as a major nitrogenated product from SMX degradation is based on findings reported in some papers regarding the fate of nitrogen atoms contained in primary amines during the PEF treatment.

\section{Conclusion}

In this study, we have demonstrated a performance comparison of the AO, AO- $\mathrm{H}_{2} \mathrm{O}_{2}, \mathrm{AO}-\mathrm{H}_{2} \mathrm{O}_{2}-\mathrm{UVA}$, EF and PEF processes for the mineralization of SMX in an acidic aqueous solution ( $\mathrm{pH} 3.0$ ). The most powerful method is the PEF process in which organic pollutants are rapidly oxidized with $\bullet \mathrm{OH}$ formed from Fenton and photo-Fenton reaction, whereas final by-products including $\mathrm{Fe}(\mathrm{III})$ complexes with carboxylic acids are efficiently destroyed with UVA light. The EF process can degrade SMX efficiently, but it is less efficient yielding total mineralization at longer electrolysis time due to the slow reaction of short intermediates (such as Fe(III)-oxalate complexes) with $\bullet \mathrm{OH}$. The slow TOC removal rate is attained during the $\mathrm{AO}-\mathrm{H}_{2} \mathrm{O}_{2}$ and $\mathrm{AO}-\mathrm{H}_{2} \mathrm{O}_{2}$-UVA methods were used. In contrast, SMX is hardly mineralized by the AO process for the poor catalytic ability of $\mathrm{RuO}_{2} / \mathrm{Ti}$ anode, which is unable to convert significant amounts of aromatic intermediates into carboxylic acids. The original nitrogen of the antibiotic drug is mainly lost as $\mathrm{NH}_{4}{ }^{+}$ion along with a very small proportion of $\mathrm{NO}_{3}{ }^{-}$ion in all cases, although their higher concentrations are achieved in the EF and PEF processes. Ion-exclusion chromatograms reveal various short chain carboxylic acids are generated in the electrolyzed solutions. The most persistent carboxylic acids are oxalic and oxamic acids, which are more rapidly removed in the PEF process because of the quicker pho- 
todegradation of Fe(III)-oxalate and Fe(III)-oxamate complexes by the UVA light. In addition, we also have identified six primary aromatic intermediates during the PEF process by means of LC-MS analysis, which is mainly issued from the hydroxylation of the aromatic ring or/and isoxazole ring, accompanied by the substitution of the amine group (aromatic cycle) or methyl group (isoxazole ring) by ${ }^{\bullet} \mathrm{OH}$. At the same time, AMI from the $\gamma$-cleavage (the $\mathrm{S}-\mathrm{N}$ bond) and sulfanilamide from the $\varepsilon$ cleavage (the $\mathrm{N}-\mathrm{C}$ bond) were also detected. A comprehensive degradation pathway for SMX mineralization that involves with the ${ }^{\bullet} \mathrm{OH}$ as the main oxidant is proposed.

\section{Acknowledgements}

The authors gratefully acknowledge the financial support of this work by Japan Society for the Promotion of Science (JSPS). This study is also partially funded by the National Natural Science Foundation of China (No. 50608068). The authors also are grateful to Mr. Takahashi S. and Dr. Yu Z.Y. for performing the HPLC and HPLC-MS analysis.

\section{References}

[1] M. Dodd, C.H. Huang, Environ. Sci. Technol 38 (2004) 5607-5615.

[2] Y. Lester, D. Avisar, H. Mamane, Environ. Technol. 31 (2010) 175-183.

[3] S. Pérez, P. Eichhorn, D.S. Aga, Environ. Toxicol. Chem. 24 (2005) 1361 1367.

[4] M. Öt Uslu, I.A. Balcioğlu, J. Agric. Food Chem. 57 (2009) 11284-11291.

[5] M.J. García-Galán, M.S. Díaz-Cruz, D. Barceló, Trends Anal. Chem. 27 (2008) 1008-1022.

[6] K. Kümmerer, Chemosphere 75 (2009) 417-434.

[7] V.K. Sharma, S.K. Mishra, N. Nesnas, Environ. Sci. Technol. 40 (2006) 7222-7227.

[8] V.K. Sharma, S.K. Mishra, A.K. Ray, Chemosphere 62 (2006) 128-134.

[9] R.F. Dantas, S. Contreras, C. Sans, S. Esplugas, J. Hazard. Mater. 150 (2008) 790-794

[10] V. Yargeau, Ch. Lecair, Ozone Sci. Eng. 30 (2008) 175-188.

[11] A.Y.-C. Lin, C.-F. Lin, J.-M. Chiou, P.K.A. Hong, J. Hazard. Mater. 171 (2009) $452-458$.

[12] M. Dodd, H.P.E. Kohler, U.V. Gunten, Environ. Sci. Technol. 43 (2009) 2498-2504.

[13] F.J. Beltrán, P. Pocostales, P.M. Álvarez, F. López-Piñeiro, Appl. Catal. B: Environ. 92 (2009) 262-270.

[14] F.J. Beltrán, A. Aguinaco, J.F. García-Araya, A. Oropesa, Water Res. 42 (2008) 3799-3808.

[15] L. Hu, P.M. Flanders, P.L. Miller, T.J. Strathmann, Water Res. 41 (2007) 2612-2626.

[16] M.N. Abellán, B. Bayarri, J. Giménez, J. Costa, Appl. Catal. B: Environ. 74 (2007) 233-241.

[17] W. Baran, E. Adamek, A. Sobczak, A. Makowski, Appl. Catal. B: Environ. 90 (2009) 516-525.

[18] Y. Lester, I. Gozlan, D. Avisar, H. Mamane, Water Sci. Technol. 58 (2008) 1147-1154.

[19] D. Avisar, Y. Lester, H. Mamane, J. Hazard. Mater. 175 (2010) 1068-1074.

[20] M.V.N. Mouamfon, W. Li, S. Lu, Z. Qiu, N. Chen, K. Lin, Environ. Technol. 31 (2010) 489-494.

[21] J.L. Tambosi, R.F. de Sena, W. Gebhardt, R.F.P.M. Moreira, H.J. José, H.F. Schröder, Ozone Sci. Eng. 31 (2009) 428-435.
[22] O. González, C. Sans, S. Esplugas, J. Hazard. Mater. 146 (2007) 459-464.

[23] D. Marciocha, J. Kalka, J. Turek-Szytow, J. Wiszniowski, J. Surmacz-Górska, Water Sci. Technol. 60 (2009) 2555-2562.

[24] A.G. Trovó, R.F.P. Nogueira, A. Agüera, A.R. Fernandez-Albab, C. Sirtori, S. Malato, Water Res. 43 (2009) 3922-3931.

[25] C. Sirtori, A. Zapata, I. Oller, W. Gernjak, A. Agüera, S. Malato, Water Res. 43 (2009) 661-668

[26] O. González, C. Sans, S. Esplugas, S. Malato, Photochem. Photobiol. Sci. 8 (2009) 1032-1039.

[27] C. Sirtori, A. Zapata, I. Oller, W. Gernjak, A. Agüera, S. Malato, Environ. Sci. Technol. 43 (2009) 1185-1191.

[28] S. Li, D. Bejan, M.S. McDowell, N.J. Bunce, J. Appl. Electrochem. 38 (2008) 151-159.

[29] J. Boudreau, D. Bejan, S. Li, N. Bunce, Ind. Eng. Chem. Res. 49 (2010) 2537-2542.

[30] M.A. Oturan, J. Peiroten, P. Chartrin, A.J. Acher, Environ. Sci. Technol. 34 (2000) 3474-3479.

[31] M.A. Oturan, J. Appl. Electrochem. 30 (2000) 475-482.

[32] I. Sirés, J.A. Garrido, R.M. Rodríguez, P.L. Cabot, F. Centellas, C. Arias, E. Brillas, J. Electrochem. Soc. 153 (2006) D1-D9.

[33] I. Sirés, A. Garrido, R.M. Rodríguez, E. Brillas, N. Oturan, M.A. Oturan, Appl. Catal. B: Environ. 72 (2007) 382-394.

[34] E. Brillas, J.C. Calpe, J. Casado, Water Res. 34 (2000) 2253-2262.

[35] E. Brillas, J. Casado, Chemosphere 47 (2002) 241-248.

[36] E. Brillas, I. Sirés, M.A. Oturan, Chem. Rev. 109 (2009) 6570-6631.

[37] E. Brillas, E. Mur, R. Sauleda, L. Sànchez, J. Peral, X. Domènech, J. Casado, Appl. Catal. B: Environ. 16 (1998) 31-42.

[38] A.M. Wang, J.H. Qu, J. Ru, H.J. Liu, J.T. Ge, Dyes Pigments 65 (2005) 227-233.

[39] A.M. Wang, J.H. Qu, H.J. Liu, J. Ru, Appl. Catal. B: Environ. 84 (2008) 393-399.

[40] A. Dirany, I. Sirés, N. Oturan, M.A. Oturan, Chemosphere 81 (2010) 594-602.

[41] E. Guinea, C. Arias, P.L. Cabot, J.A. Garrido, R.M. Rodríguez, F. Centellas, E. Brillas, Water Res. 42 (2008) 499-511.

[42] C. Flox, J.A. Garrido, R.M. Rodríguez, P.L. Cabot, F. Centellas, C. Arias, E. Brillas, Catal. Today 129 (2007) 29-36.

[43] M. Skoumal, C. Arias, P.L. Cabot, F. Centellas, J.A. Garrido, R.M. Rodríguez, E. Brillas, Chemosphere 71 (2008) 1718-1729.

[44] M. Skouma, R.M. Rodríguez, P.L. Cabot, F. Centellas, J.A. Garrido, C. Arias, E. Brillas, Electrochim. Acta 54 (2009) 2077-2085.

[45] E. Isarain-Chávez, C. Arias, P.L. Cabot, F. Centellas, R.M. Rodríguez, J.A. Garrido, E. Brillas, Appl. Catal. B: Environ. 96 (2010) 361-369.

[46] A.L. Boreen, W.A. Arnold, K. Mcneill, Environ. Sci. Technol. 38 (2004) 3933-3940.

[47] A.G. Trovó, R.F.P. Nogueira, A. Agüera, C. Sirtori, A.R. Fernández-Alba, Chemosphere 77 (2009) 1292-1298.

[48] A.M. Wang, Y.Y. Li, J. Ru, J. Chem. Technol. Biotechnol. 85 (2010) 1463-1470

[49] E.V. Rokhina, E.A. Golovina, V.A. Henk, J. Virkutyte, Chemosphere 77 (2009) $148-150$.

[50] J. Wang, W. Zhu, S. Yang, W. Wang, Y. Zhou, Appl. Catal. B: Environ. 78 (2008) 30-37.

[51] Q. Wang, A.T. Lemley, Environ. Sci. Technol. 35 (2001) 4509-4514.

[52] N. Borràs, R. Oliver, C. Arias, E. Brillas, J. Phys. Chem. A 114 (2010) 6613-6621.

[53] A.M. Wang, J.H. Qu, H.J. Liu, J.T. Ge, Chemosphere 55 (2004) 1189-1196.

[54] P. Calza, C. Medana, M. Pazzi, C. Baiocchi, E. Pelizzetti, Appl. Catal. B: Environ. 53 (2004) 63-69.

[55] M.A. Oturan, E. Guivarch, N. Oturan, I. Sirés, Appl. Catal. B: Environ. 82 (2008) 244-254.

[56] A. Serra, X. Domènech, J. Peral, C. Arias, E. Brillas, J. Environ. Eng. Manage. 18 (2008) 173-181.

[57] A. Serra, X. Domènech, C. Arias, E. Brillas, J. Peral, Appl. Catal. B: Environ. 89 (2009) 12-21.

[58] A. Özcan, Y. Sahin, A.S. Kopoaral, M.A. Oturan, Appl. Catal. B: Environ. 89 (2009) 620-626.

[59] A. Rodayan, R. Roy, V. Yargeau, J. Hazard. Mater. 177 (2010) 237-243.

[60] V. Yargeau, J.C. Huot, A. Rodayan, L. Rouleau, R. Roy, R.L. Leask, Environ. Toxicol 23 (2008) 492-498. 